\title{
PREVALENCE, RISK FACTORS, AND MODE OF TREATMENT FOR PRIMARY DYSMENORRHEA IN FEMALE HIGH SCHOOL STUDENT IN SURAKARTA, CENTRAL JAVA
}

\author{
Dita Wrisnijati'), Budiyanti Wiboworini' ${ }^{2}$, Sugiarto²) \\ 1)Masters Program in Nutrition, Universitas Sebelas Maret \\ ${ }^{2)}$ Faculty of Medicine, Universitas Sebelas Maret
}

\begin{abstract}
Background: Primary dysmenorrhea is the most common health problem of female adolescents. This results in adverse physical, psychological, and social consequences. This study aimed to determine prevalence, risk factors, and mode of treatment for primary dysmenorrhea in female high school student in Surakarta, Central Java.

Subjects and Method: This was an analytic observational study with a crosssectional design. The study was conducted in Surakarta, Central Java, from September to October 2017. A sample of 725 female students aged 15-18 years was selected for this study by simple random sampling. The dependent variable was dysmenorrhea. The independent variables were age, family history of dysmenorrhea, oligomenorrhea, and menstrual duration. The data of dysmenorrhea were measured by numeric rating scale (NRS). Other variables were collected by questionnaire. The data were analyzed by a multiple logistic regression.
\end{abstract}

Results: Dysmenorrhea prevalence was 88.7\%. 339 (62.1\%) female students were experienced mild dysmenorrhea, moderate (226 female students, 35.1\%), and severe (18 female students, 2.8\%). The risk of dysmenorrhea increased with early menarche $(\mathrm{OR}=0.02 ; 95 \% \mathrm{CI}=0.01$ to $0.33 ; \mathrm{p}<0.001)$, family history of dysmenorrhea $(\mathrm{OR}=0.91 ; 95 \% \mathrm{CI}=0.05$ to $0.17 ; \mathrm{p}<0.001)$, oligomenorrhea $(\mathrm{OR}=$ $0.17 ; 95 \% \mathrm{CI}=0.10$ to $0.25 ; \mathrm{p}<0.001)$, and metrorrhagia $(\mathrm{OR}=1.52 ; 95 \% \mathrm{CI}=0.73$ to $3.14 ; \mathrm{p}=0.260$ ). As many as $43.8 \%$ female students used home medication (e.g. warm water compress), $0.9 \%$ took non-prescription analgetics, $0.6 \%$ sought medical advice, $26.8 \%$ took two kinds of medication, and $27.9 \%$ took no medication.

Conclusion: The risk of dysmenorrhea increases with early menarche, family history of dysmenorrhea, oligomenorrhea, and metrorrhagia.

Keywords: dysmenorhrea, risk factors, prevalence

\section{Correspondence:}

Dita Wrisnijati. Masters Program in Nutrition, Universitas Sebelas Maret, Jl. Ir.Sutami No. 36 A, 57126, Surakarta, Central Java.

Email: Ditawrisnijati@gmail.com. Mobile: 081225477964.

Mid-International Conference in Public Health, Best Western Premiere Hotel, Solo, Indonesia, 18-19 April 2018 | 182 https://doi.org/10.26911/mid.icph.2018.03.18 